\title{
Effect of Bacteria on Scape Bending in Cut Gerbera jamesonii Flowers
}

\author{
Wouter G. van Doorn and Yke de Witte \\ Agrotechnological Research Institute (ATO-DLO), P.O. Box 17, 6700 AA Wageningen, The Netherlands
}

Additional index words. Pseudomonas aeruginosa, cut flowers, scape curvature, water potential

\begin{abstract}
Including bacteria in the vase water of cut Gerbera jamesonii Bolus flowers resulted in an increase in scape curvature depending on the concentration of bacteria in the water, cultivar, and season. In the summer, a strain of Pseudomonas aeruginosa or a mixed population of bacterial species, all isolated from the vase water of cut gerbera flowers, resulted in curvature of $>90^{\circ}$ in 'Liesbeth' at $10^{8} \mathrm{cfu} / \mathrm{ml}$ and in 'Mickey' at $10^{10} \mathrm{cfu} / \mathrm{ml}$. In winter, the lowest bacterial concentrations that resulted in such bending were $10^{6}$ and $10^{8} \mathrm{cfu} / \mathrm{ml}$, respectively. 'Mickey' showed bending at a lower water potential than 'Liesbeth'. Comparison between these results and the bacterial counts in vase water and water at retail shops indicates that frequently observed scape bending is at least partly due to bacteria.
\end{abstract}

The scapes of cut gerbera flowers often bend and break when they are placed in water, but including antibacterial compounds such as silver nitrate (Penningsfeld and Forchthammer, 1966; Rudnicki and Nowak, 1976; Steinitz, 1984), sodium hypochlorite, and dichlorophen (van Meeteren, 1978) in the vase water decreased the number of bent scapes. The minimum concentration of silver nitrate required to avoid bending was similar to the concentration required to inhibit bacterial growth in the water (van Meeteren, 1978). These data suggest an association between a high population density of bacteria in the water and scape bending.

We found that cut roses placed in water wilted early when the number of bacteria in the xylem was high (van Doorn et al., 1986, 1989). We hypothesized that the same relationship applied to scape bending in cut gerberas. This hypothesis was investigated by including bacteria in the vase solution. In preliminary experiments, we placed cut flowers of 10 gerbera cultivars in water. Among these, the scapes of 'Liesbeth' gerberas were most apt to bend, while those of 'Mickey' were most rigid. In the present experiments, the effect of exogenous bacteria was compared in these two cultivars.

\section{Materials and Methods}

Plant material. Cut 'Liesbeth' and 'Mickey' gerbera flowers with a scape length of $\approx 40 \mathrm{~cm}$ were obtained from a commercial grower. After harvest, the flowers were held dry at $\approx 20 \mathrm{C}$ for no more than $4 \mathrm{~h}$. Subsequently, $\approx 10 \mathrm{~cm}$ was cut from the basal end of the scape giving a final length of $30 \mathrm{~cm}$, and the cut flowers were held in glass bottles containing deionized water. The bottles had been washed but not sterilized before use. The flowers were held in a climate-controlled room at 20C, $60 \%$ relative humidity, and a photosynthetically active quantum flux of $15 \mu \mathrm{mol} \cdot \mathrm{m}^{-2} \cdot \mathrm{s}^{-1}$ from cool-white fluorescent tubes, which were on $12 \mathrm{~h}$ daily.

Bacterial suspensions. Bacterial samples were obtained from the vase water of 'Mickey' flowers held in the climate-controlled room for 7 days. Water samples were then placed on plate count agar (Oxoid, Basingstoke, Hants, U.K.) using a spiral plate machine (model C; Spiral Plate Systems, Cincinnati). Bacterial colonies were incubated for 2 days at 30C and then collected and placed in distilled water. The concentration was adjusted to $10^{10} \mathrm{cfu} / \mathrm{ml}$,

Received for publication 7 June 1993. Accepted for publication 17 Aug. 1993. The cost of publishing this paper was defrayed in part by the payment of page charges. Under postal regulations, this paper therefore must be hereby marked advertisement solely to indicate this fact. and this concentrated suspension was used to formulate dilute concentrations of $10^{4}, 10^{5}, 10^{6}, 10^{7}, 10^{8}$, and $10^{9} \mathrm{cfu} / \mathrm{ml}$. One of the most frequently observed colony types (based on shape and color) was grown to pure culture and identified using the OXI/FERM system (Hoffmann-La Roche, Basle, Switzerland) as Pseudomonas aeruginosa. This strain was also grown on plate count agar and placed in distilled water at $10^{10} \mathrm{cfu} / \mathrm{ml}$ or in decimal dilutions.

Ten replicate flowers were placed in these bacterial suspensions at the onset of vase life and left in these suspensions for 8 days. The water was not replenished.

Water potential. The water potential of the petals from the ray florets was measured on day 3 of vase life using a Scholander pressure chamber (Scholander et al., 1965) and seven replications. The chamber interior was kept moist by lining it with wet filter paper. The petals were cut at their base and placed in the chamber within seconds. Preliminary experiments showed that water potential of the petals was linearly correlated with the water potential of the scapes, but variation was less in petals.

Determination of bacterial numbers in water and in gerbera scapes. The number of bacteria in the lowermost $5 \mathrm{~cm}$ of the scapes was measured in three replicate scapes after surface-sterilization with sterile tissue drenched in $98 \%$ ethanol. The scape segment was then cut in parts $0.5 \mathrm{~cm}$ long using sterile clippers. The parts were placed in sterilized bags and weighed. A sterile $0.85 \mathrm{NaCl}$ solution was added, 10 times the weight of the scape parts. The bacteria were removed from the parts in a model 40 Colworth Stomacher (Seward \& Co., London) for $1 \mathrm{~min}$. Samples of the solution were then placed on plate count agar. The petri dishes were kept at $30 \mathrm{C}$ for $48 \mathrm{~h}$ before enumeration.

To compare the results with the number of bacteria found in practice, water was sampled at the premises of some growers and in flower shops. The owners were not informed of the sampling date. Samples were taken at 32 growers in Holland, 87 retailers in various European countries, and 8 retailers in the United States, one sample per grower or retailer. The survey was conducted from 1 Oct. 1987 to 1 Apr. 1988. The number of bacteria in the water was determined by stirring the water and placing dipslides (<Urotube>Roche, Hoffmann-La Roche, Basle, Switzerland) in the water for 1 to $2 \mathrm{sec}$. These slides contained cysteine-lactose-electrolyte-deficient agar used to determine the total bacterial count. The slides were held at $30 \mathrm{C}$ for 24 $\mathrm{h}$, and the number of colonies on the agar was compared with a photoseries showing the number of bacteria per milliliter of water. Preliminary tests had shown that incubation for $24 \mathrm{~h}$ gave the same results as the standard 48 h of incubation used when counting colonies on plate count agar. 
Scape bending. At the onset of vase life, the scapes were fully turgid and were placed in the vials under an angle of $\approx 20^{\circ}$ with respect to vertical. Scape curvature was measured daily using a protractor and expressed with respect to the angle on day 0 of vase life.

Statistics. All experiments were repeated at least once. The results were compared by analysis of variance using the GENSTAT V program and F test at $P<0.05$.

\section{Results}

Number of bacteria in the vase solution and in scapes. When the flowers were individually placed in vases containing water with a low number of bacteria, the bacterial count in the vase solution increased to a maximum of $\approx 10^{8} \mathrm{cfu} / \mathrm{ml}$ after 8 days and the number of bacteria in the basal 5 -cm segment of the scapes increased to $\approx 10^{9} \mathrm{cfu} / \mathrm{g}$ fresh weight. Scapes of 'Mickey' and 'Liesbeth' flowers contained similar numbers of bacteria (Fig. 1).

Effects of increased bacterial counts in the vase water. In a typical experiment with 'Liesbeth' flowers in winter, the scapes placed in a suspension of $10^{4}$ or $10^{5} \mathrm{cfu} / \mathrm{ml}$ had about the same degree of curvature as controls, but at $10^{6}$ and $10^{7} \mathrm{cfu} / \mathrm{ml}$ the scapes were progressively more curved than in controls (Fig. 2). Bending occurred within a few days after including the bacteria and it often led to stem breakage, especially in the presence of high bacterial concentrations in the water. A pure culture of $P$. aeruginosa included in the vase water had a similar effect as a suspension of mixed bacteria containing the same number of colony forming units (Table 1).

Effects of the season and cultivar. In experiments during summer, 'Mickey' gerbera flowers developed a scape curvature of $>90^{\circ}$ when placed in bacterial concentrations of $10^{10} \mathrm{cfu} / \mathrm{ml}$, and in 'Liesbeth', such scape bending occurred from $10^{7} \mathrm{cfu} / \mathrm{ml}$ (Fig. 2). In winter, the concentrations of bacteria causing such scape bending were $\approx 10^{2}$ lower than in summer (Fig. 2).

Effects of bacteria on water relations. Adding bacteria to the vase water resulted in a decrease in water potential of the ray florets. When placed in $10^{8} \mathrm{cfu} / \mathrm{ml}$ of bacteria, scape bending to $>90^{\circ}$ in 'Liesbeth' flowers occurred at a higher water potential than

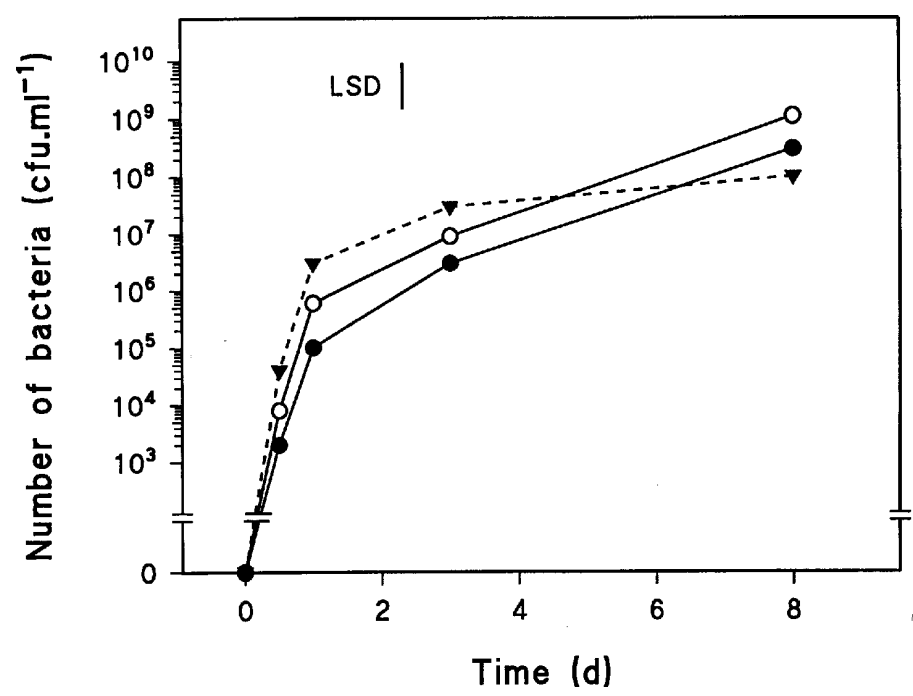

Fig. 1. Number of bacteria in the vase water $(\boldsymbol{\nabla}$, in $\mathrm{cfu} / \mathrm{ml})$ and in the basal $5 \mathrm{~cm}$ of the scape (in cfu/g fresh weight) of cut Gerbera jamesonii flowers of 'Mickey' (O) and 'Liesbeth' (O), held in the water at 20C for 8 days. Data are means of three replications. LSD value refers to the bacterial counts in scapes at $P<0.05$. in 'Mickey' flowers (Fig. 3).

Relationship between number of bacteria in scapes and scape bending. After including the mixed bacterial flora in the vase solution, bending to $>90^{\circ}$ in 'Liesbeth' flowers occurred when the number of bacteria in the basal $5 \mathrm{~cm}$ of the scape exceeded $10^{8} \mathrm{cfu} /$ $\mathrm{g}$ fresh weight and in 'Mickey' flowers when the number of bacteria exceeded $\approx 10^{10} \mathrm{cfu} / \mathrm{g}$ fresh weight. The same relationship between bacterial counts in scapes and scape bending was found after including $P$. aeruginosa in the vase water (Table 2).

Bacterial counts in commercial containers used for gerbera flowers. Before sale, gerbera flowers are generally kept in solutions at growers, wholesalers, and retailers. Our samples of the water used by Dutch gerbera growers always contained $<10^{6} \mathrm{cfu} /$ $\mathrm{ml}$ (Fig. 4). These solutions contained sodium hypochlorite as an antibacterial agent.

In water samples from flower shops the bacterial count was higher. No clear differences were found between the distribution

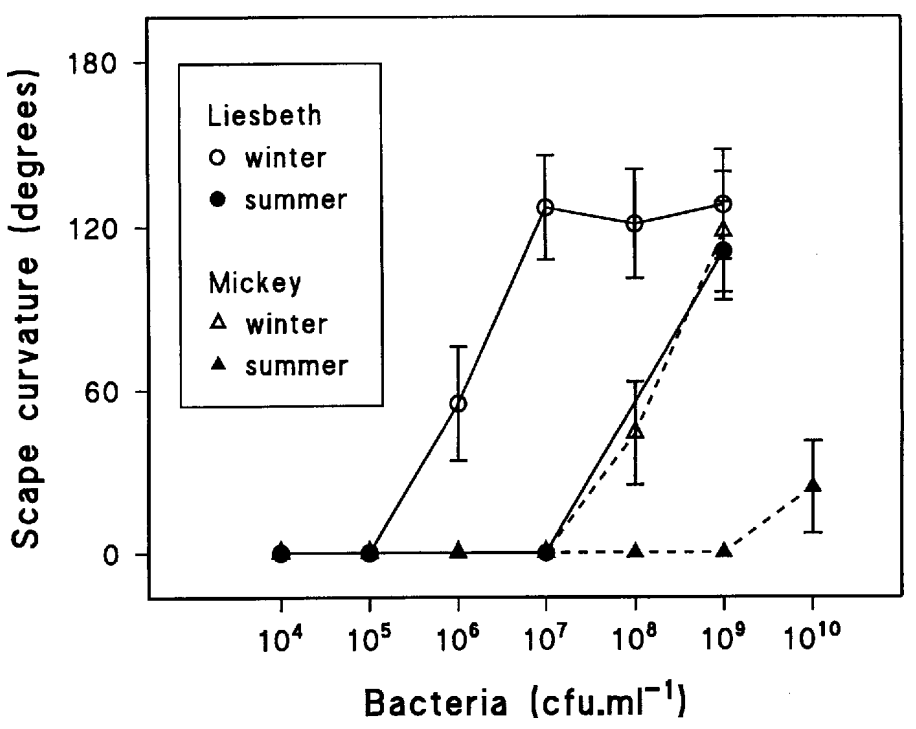

Fig. 2. Relationship between the number of bacteria included in the vase water (on day 0 ) and scape curvature (on day 3 ; in degrees with respect to day 0 ) in cut Gerbera jamesonii flowers of 'Liesbeth' and 'Mickey'. Data are the means of 10 replications $\pm \mathrm{SD}$

Table 1. Relationship between the number of bacteria included in the vase water on day 0 (in $\mathrm{cfu} / \mathrm{ml})$ and the number of scapes of cut Gerbera jamesonii flowers that had bent $>90^{\circ}$ on day $3 .^{\mathrm{z}}$

\begin{tabular}{lcr}
\hline \hline \multirow{2}{*}{$\begin{array}{l}\text { No. of } \\
\text { bacteria }\end{array}$} & \multicolumn{2}{c}{ Scapes bent $>90^{\circ}(\% \text { of total })^{\mathrm{y}}$} \\
\cline { 2 - 3 } & Mickey & Liesbeth \\
\hline $0^{5}$ & Mixed bacterial population $(\mathrm{cfu} / \mathrm{ml})$ & 0 \\
$10^{6}$ & 0 & 20 \\
$10^{7}$ & 0 & 100 \\
& 10 & \\
$10^{5}$ & Pseudomonas aeruginosa $(\mathrm{cfu} / \mathrm{ml})$ & 0 \\
$10^{6}$ & 0 & 20 \\
$10^{7}$ & 0 & 90 \\
$10^{8}$ & 0 & 100 \\
$10^{9}$ & 20 & 100
\end{tabular}

${ }^{\mathrm{z}}$ Scapes were placed a suspension of $P$. aeruginosa isolated from gerbera vase water or in a mixture of the bacterial strains occurring in vase water. The experiment was conducted in winter.

${ }^{\mathrm{y}}$ Sample size was 10. 


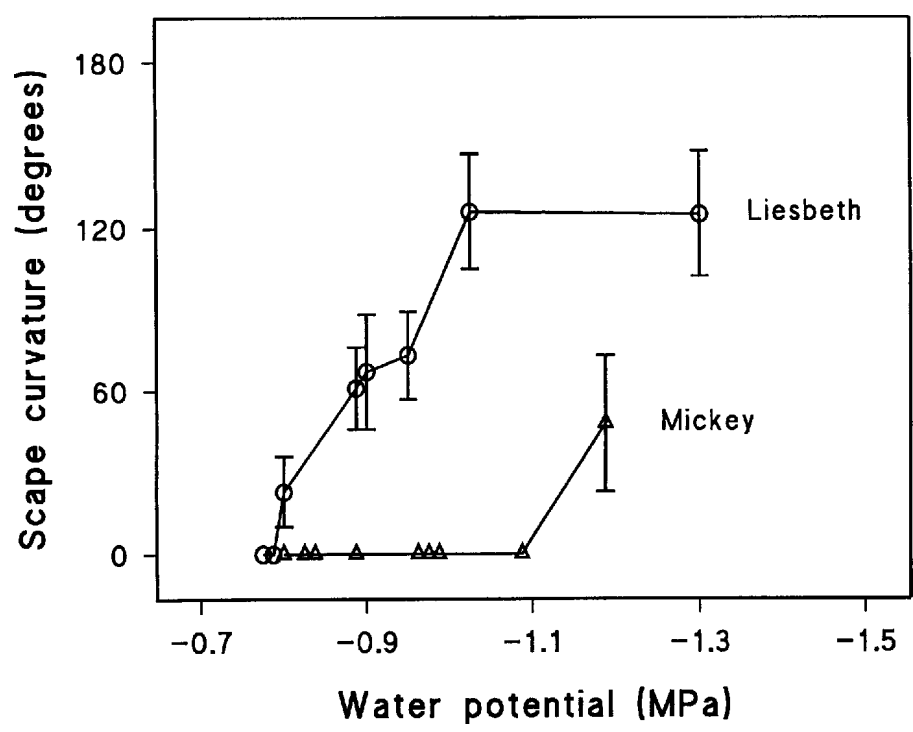

Fig. 3. Relationship between scape curvature (in degrees with respect to day 0) of cut Gerberajamesonii flowers of 'Liesbeth' and 'Mickey' and the water potential of the petals from the ray florets on day 3 of vase life. Curvature data are the means of 10 replications $\pm \mathrm{SD}$.

Table 2. Relationship between the number of bacteria included in the vase water on day 0 (in cfu/ml), the number of bacteria in the basal $5 \mathrm{~cm}$ of the scapes of cut Gerbera jamesonii flowers after 6 days of vase life ${ }^{\mathrm{z}}$, and scape bending. ${ }^{\mathrm{y}}$

\begin{tabular}{|c|c|c|}
\hline \multirow{2}{*}{$\begin{array}{l}\text { No. of bacteria } \\
\text { in vase water }\end{array}$} & \multicolumn{2}{|c|}{$\begin{array}{l}\text { No. of bacteria in the basal } 5 \mathrm{~cm} \\
(\mathrm{cfu} / \mathrm{g} \text { fresh weight })^{\mathrm{x}}\end{array}$} \\
\hline & Mickey & Liesbeth \\
\hline \multicolumn{3}{|c|}{ Mixed bacterial population $(\mathrm{cfu} / \mathrm{ml})$} \\
\hline Control & $4.8 \times 10^{7}$ & $5.0 \times 10^{7}$ \\
\hline $10^{6}$ & $5.4 \times 10^{8}$ & $5.4 \times 10^{8}{\text { (bent })^{\mathrm{x}}}$ \\
\hline $10^{7}$ & $2.6 \times 10^{9}$ & $2.9 \times 10^{9}$ (bent) \\
\hline $10^{8}$ & $9.8 \times 10^{9}(\text { bent })^{\mathrm{y}}$ & $8.7 \times 10^{9}$ (bent) \\
\hline $10^{9}$ & $1.3 \times 10^{10}($ bent $)$ & $2.4 \times 10^{10}$ (bent) \\
\hline \multicolumn{3}{|c|}{ Pseudomonas aeruginosa $(\mathrm{cfu} / \mathrm{ml})$} \\
\hline Control & $3.6 \times 10^{7}$ & $7.9 \times 10^{6}$ \\
\hline $10^{6}$ & $1.6 \times 10^{8}$ & $4.5 \times 10^{7}$ \\
\hline $10^{7}$ & $9.5 \times 10^{8}$ & $1.6 \times 10^{8}$ (bent) \\
\hline $10^{8}$ & $6.8 \times 10^{8}$ & $7.8 \times 10^{8}$ (bent) \\
\hline $10^{9}$ & $3.1 \times 10^{10}$ (bent) & $2.0 \times 10^{10}$ (bent) \\
\hline
\end{tabular}

${ }^{\mathrm{z}}$ Scapes were placed in a suspension of $P$. aeruginosa isolated from gerbera vase water or in a mixture of the bacterial strains occurring in vase water. The experiment was conducted in winter.

y Bending refers to a degree of curvature $>90^{\circ}$ in $>50 \%$ of the scapes.

${ }^{\mathrm{x}}$ Means of three replicate scapes, $\mathrm{LSD}=9.3 \times 10^{1}$

of bacterial counts in the samples from the various countries investigated (data not shown). Counts of $10^{5}$ and $10^{6} \mathrm{cfu} / \mathrm{ml}$ were most frequently found. Taken together, a count of $10^{8}$ or $10^{9} \mathrm{cfu} /$ $\mathrm{ml}$ was found in $\approx 10 \%$ of the containers sampled (Fig. 4 ).

\section{Discussion}

The results show that the frequently observed bending of the scapes of cut gerbera flowers placed in water may, at least partially, be due to bacteria. A sensitive cultivar showed increased scape curvature at an initial exogenous concentration of bacteria of $10^{6}$ $\mathrm{cfu} / \mathrm{ml}$. At the growers, low bacterial counts were found in the water. About $25 \mathrm{mg} \cdot \mathrm{ml}^{-1}$ sodium hypochlorite, an effective anti-

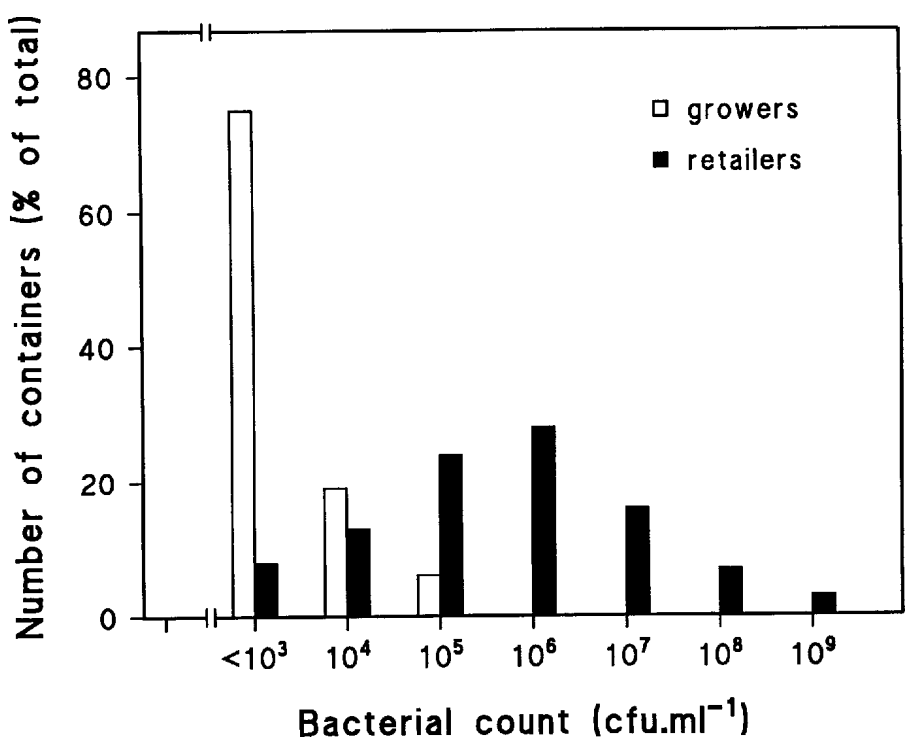

Fig. 4. Frequency of bacterial counts in water samples from containers used for standing cut Gerbera jamesonii flowers. Frequency refers to the number of containers, as a percentage of the total, containing a bacterial count (in cfu/ml) of a certain category. Samples were taken at 32 growers (open bars) in Holland (one sample per grower) and in flower shops (filled bars) located in West Germany (24), France (19), U.K. (10), Italy (16), Holland (15), United States (8) and Sweden (5), one sample per outlet. The number between brackets refers to the number of samples in each country.

bacterial agent (van Doorn et al., 1990), was included in the water. At retail shops, however, an antibacterial compound was usually not included, and the water generally contained $10^{5}$ to $10^{7} \mathrm{cfu} / \mathrm{ml}$ of bacteria, but $10^{8}$ or $10^{9} \mathrm{cfu} / \mathrm{ml}$ was observed in $\approx 10 \%$ of the samples (Fig. 4).

Because the scapes have a pubescent surface and grow close to the soil, they may carry a high number of bacteria. Put (1988) found a much higher number of bacteria on the basal $10 \mathrm{~cm}$ of the scapes of freshly harvested 'Fleur' and 'Appleblossom' gerbera flowers than on the basal $10 \mathrm{~cm}$ of 'Sweet Promise' (Sonia) rose stems. The number of bacteria in a vase solution containing one rose flower reached $10^{6} \mathrm{cfu} / \mathrm{ml}$ after 2 to 3 days (de Witte and van Doorn, 1988), and the same number was reached in vases containing one gerbera flower after 1 day (Fig. 1). Whether the rapid increase in bacterial numbers in the vase water of gerberas is due solely to the number of bacteria on the scape surface is, however, not known.

Freshly cut flowers placed in a suspension of bacteria showed scape bending within 3 days. The curvature was related to the water potential of the ray petals, which suggests that scape bending is due to a low water potential. In cut rose flowers, we found that bacteria block the xylem conduits, resulting in low turgor (van Doorn et al., 1986, 1989). Bending of the gerbera scapes may similarly be produced by low turgor. In 'Liesbeth' flowers, an average scape curvature of $\approx 60^{\circ}$ occurred at a water potential of about $-0.9 \mathrm{MPa}$ and in 'Mickey' flowers at a water potential below -1.2 MPa (Fig. 4). This indicates that the bending is not only related to the water potential, but depends on other, cultivar-specific properties. Dubuc-Lebreux and Vieth (1985) and Marousky (1986) have suggested that scape anatomy, especially the number of supportive elements and the degree of lignification of the xylem, may be involved in bending during vase life.

The scapes were more susceptible to exogenous bacteria in winter than summer. In winter, bending to $>90^{\circ}$ often occurred at $10^{6} \mathrm{cfu} / \mathrm{ml}$ in 'Liesbeth' and at $10^{8} \mathrm{cfu} / \mathrm{ml}$ in 'Mickey', while in summer bending occurred at concentrations of $10^{8}$ and $10^{10} \mathrm{cfu} / \mathrm{ml}$, respectively. These results indicate that, in winter, the numbers of 
bacteria found in water at some retailers may result in stem bending even in the least-sensitive cultivars.

Increased bending in winter compared to summer indicates that scape rigidity is affected by ambient conditions during growth. During winter, the temperatures in the greenhouse are not much lower than in summer, but light levels are much reduced. Compared to the normal incident light, additional lighting in the greenhouse reduced the number of bent scapes of cut 'Rosamunde' gerbera flowers placed in water directly after harvest (van Os and de Koster, 1989). Low light intensity may, therefore, have an effect on scape properties that may be related to bending, such as the osmotic potential in the cytoplasm and cell wall structure, including lignification.

\section{Literature Cited}

de Witte, Y. and W.G. van Doorn. 1988. Identification of bacteria in the vase water of roses and the effect of the isolated strains on water uptake. Sci. Hort. 35:285-291.

Dubuc-Lebreux, M.A. and J. Vieth. 1985. Histologie du pédoncule inflorientiel de Gerbera jamesonii. Acta Bot. Neerl. 34:171-182.

Marousky, J. 1986. Vascular structure of the gerbera scape. Acta Hort. 181:399-405.

Penningsfeld, F. and L. Forchthammer. 1966. Silbernitrat verbessert die Haltbarkeit geschnittener Gerbera. Gartenwelt 66:226-228.
Put, H.M.C. 1990. Micro-organisms from freshly harvested cut flower stems and developing during the vase life of chrysanthemum, gerbera and rose cultivars. Sci. Hort. 43:129-144.

Rudnicki, R.M. and J. Novak. 1976. Vase life of Gerbera jamesonii Bolus cut flowers depending upon media, mineral nutrition, their morphological attributes, and treatment with flower preservatives. Acta Agrobot. 29:289296.

Scholander, P.F., H.T. Hammel, E.D. Bradstreet, and E.A. Hemmingsen. 1965. Sap pressures in vascular plants. Science 148:339-346.

Steinitz, B. 1984. The influence of sucrose and silver ions on dry weight, fiber and lignin contents, and stability of cut gerbera flower stalks. Gartenbauwissenschaft 48:67-71.

van Doorn, W.G., H.C.E.M. Buis, and Y. de Witte. 1986. Effect of endogenous bacteria on water relations of cut rose flowers. II. Bacteria in the vase water. Acta Hort. 181:463-465.

van Doorn, W.G., Y. de Witte, and R.J.J. Perik. 1990. Effects of antimicrobial compounds on the number of bacteria in stems of cut rose flowers. J. Applied Bacteriol. 68:117-122.

van Doorn, W.G., K. Schurer, and Y. de Witte. 1989. Role of endogenous bacteria in vascular blockage of cut rose flowers. J. Plant Physiol. 134:375-381.

van Meeteren, U. 1978. Water relations and keeping quality of cut gerbera flowers. I. The cause of stem break. Sci. Hort. 8 65-74.

van Os, P.C. and R.D. de Koster. 1989. Influence of assimilation lighting on production, quality, and keepability of Gerbera. (In Dutch.) Res. Sta. Floricult., Aalsmeer. Rpt. 83. 